\title{
How Colours are Semantically Construed in the Arabic and English Culture: A Comparative study
}

\author{
Amna A.Hasan \\ Department of English Language, \\ Sohar College of Applied Sciences, Ministry of Higher Education. Sohar, Oman \\ E-mail: amnaah.soh@cas.edu.om \\ Nabiha.S.Mehdi Al-Sammerai \\ Department of Dakwah \& Human Development, Academy of Islamic Study, University Malaya \\ 50603 Kuala Lumpur, Malaysia \\ Fakhrul Adabi Bin Abdul Kadir \\ Department of Dakwah \& Human Development, Academy of Islamic Study, University Malaya \\ 50603 Kuala Lumpur, Malaysia
}

Received: October 23, 2010 Accepted: January 7, 2011 doi:10.5539/elt.v4n3p206

\begin{abstract}
Most works in cognitive semantics have been focusing on the manner, in which an individual behaves - be it the mind, brain, or even computers, which process various kinds of information. Among humans, in particular, social life is richly cultured. Sociality and culture are made possible by cognitive studies; they provide specific inputs to cognitive processes (Wilson \& Keil, 1999). The current work focussed on the use of colours as a term throughout the Arabic and English culture. In fact, one colour may imply different meanings at the same place, and this makes us ponder on how colours are construed in cross cultural diversity? In this vein, the current work referred to the etymological meaning of the colour terms, and provided six basic Arabic colour terms and cross to six English colour terms. Using the cognitive cultural categorization for each colour term, three different meanings were identified - basic meaning, extended meaning and additional meaning. 'Basic meaning' refers to the original meaning of the colour term, whereas 'extended meaning' refers to the meaning extended from the original meaning throughout human experience and 'additional meaning' refers to the meaning which has been further abstracted from the extended meaning. Thus, the aim of this work was to show how meanings of colours are identified in the different cultures of Arabic and English, and in the way whereby both languages are relevant and different for each colour term.
\end{abstract}

\section{Background}

Every language has a set of basic colour terms. However, these colour terms do not divide the meanings of colour in the same place. In other words, the cognitive linguistic concept for "colour" is idiosyncratically reflected in each language. According to (Wilson \& Keil, 1999), "the study of culture is of relevance to cognitive science for two major reasons. The first is that the very existence of culture, for an essential part, is both an effect and an appearance of human cognitive abilities. The second reason is related to the culture of today's human societies, i.e. from every aspect of human life, and in particular, of cognitive activity.

This fact is particularly true for all the societies studied by anthropologists from New Guinea to Silicon Valley. Human cognitive takes place in a social and cultural context. It uses tools provided by culture: words, concepts, beliefs, experiences, books, microscopes and computers. Moreover, a great deal of cognitive is about social and cultural phenomena." Thus the two possible views, the cultural and cognitive views, are reasonable and should be parallel (Brown, 2005). In this research, culture and cognitive were connected in the attempt to highlight the similarities and differences as well as the probability for greater cross cultural semantics account.

Thus, this study examined the semantic of the colour terms in Arabic, and compared them with the terms in English language so as to show how colour terms in these two different languages extend their semantic functions from their original to different meanings based on the cultural data. The results of this work should provide evidence which supports the view that the meanings of colour have accordingly varied based on certain universal identifiable human experience, which also extends our understanding of why some colour terms appear to have different semantic 
meanings or functions cross-linguistically, despite the fact that they have similar mechanisms in expanding their meanings, as well as the reasons why some colour terms appear to have negative and positive meanings. The discussion of the current work is organized as follows; Section 2 reviews and analyzes the semantic extension of the terms for colours in Arabic, while Section 3 compares the characteristic and the semantic extensions of the English and Arabic cultures; Section 4 provides the conclusion of the study.

\section{Arabic Basic Colour Terms}

There are six basic colours considered in the Arabic culture, namely black, white, red, green, blue and yellow although the Arabs recognize eleven basic colour terms (white, black, green, blue, red, yellow, grey, brown, pink, orange and purple), like any other languages. For the purpose of conducting viability comparison with other languages, the present research studied six most commonly used colours in the Arabic culture, and concentrated on the human experience which also included the process of their negative and positive meanings.

Each colour term uses three types of meaning; the basic meaning refers to the original meaning of the colour term, while the extended meaning refers to the meaning extended from the original meaning through human experiences, and the additional meaning is the meaning which has been further abstracted from the extended meaning. In this study, the first basic meaning is always the earliest meaning; after that, the extended meaning is developed and the abstract meaning is the most recent extension of any given colour term.

According to Xing (2008), Tao (1994), Baxter (1983) and Hays et al. (1972), white and black are the two colours which have the longest history among all the colour terms in all languages in the world, and this is also true in the Arabic culture, because they are the most contrastive and easily identified colours. As illustrated below, the Arab convoys a wide range of meanings to white colour term:

2.1 White (abiath, ابيـــ)

a. Colour basic meaning $=$ white $(+)$

The primary symbolism of this colour is the colour of nature, for which reason it is associated for, such as clouds, cotton, crystal, water and air (Houghton, 2007).

b.Extended meaning $=$ clear, clean and pure $(+)$

The first extended (clear, clean and pure) meaning, from the colour white, with the positive assumption that if something is white, it is not stained and therefore clean. Meanwhile, innocence obviously refers to white clear idea. In other words, if one has a clear or pure mind, liberally, this person a clear tolerance of matters.

\section{c. Additional meaning $=(+-)$}

The second type is the additional meaning which involves the extension to more abstract meanings (Salah, 2006), as shown below:

i.Future $=$ The word future abstracted from the white colour which means the positive outlook or hope, as good as white colour $(+)$.

ii. Peace $=$ Peace in Arabic culture refers to the end of war, "army hold white flag to show peace and settlement" $(+)$.

iii. Wedding $=$ Another positive abstracted meaning is wedding, which refers to the white gown of a bride in her dowry or wedding ceremony; in some Arabic cultures, a bride wears a white dress and puts seven white things in front of bride and groom (sugar, salt, water, milk, yogurt, mirror, silver white coins) to wish them a happy and good life as implied by white $(+)$.

iv. Virgin = In the Arabic culture, this word normally refers to unmarried females, as in 'as white as a virgin.' Otherwise, Arab negatively associate red to her to signify the meaning of stain or blood $(+)$.

v. Prayers $=$ From the religious perspective, this refers to the positive meaning of purity, virtue or innocence, and for this reason, Arabs normally wear white dresses during their pilgrimage or prayers as a sign of respect to their God and religion $(+)$.

vi. Dove $=$ Dove has a positive meaning which is associated with white; a white dove implies the meaning of a messenger who is holding white or good news. In the Arabic culture, to see a white dove means to get good news and a happy future. $(+)$

vii. Coffin $=$ However, white has a strong negative association with shrouds and the pallor of death, and hence with spectral apparitions and death. In other words, the Arabic culture refers to the 'sing of death, the dead person buries with a white coffin (-).'

In addition, the meanings of white is also extended to the idiom, as 'white hand, white heart, white face, white lies, 
white hair, and white day'; all these positive terms indicate the meaning of white in their cultural experiences as:

i. white hand $=$ Generous, kind and humanitarian.

ii. white heart $=$ Kind and honest.

iii. white eye $=$ Blind, meaning the person being addressed is blind.

vi. white face $=$ White face, innocent and youthful person.

v. white lies = as "White lies" an untruth told to spare feelings or from politeness.

iv. white hair $=$ White hair, refers to old aged people or wisdom or good sense.

iiv. white day = White day, in the Arabic culture indicates the abstract positive meaning of good, fine and worthy day.

iiiv. white days $=$ In the Arabic culture or the Islamic calendar, 13, 14, 15 white days are associated with the moon growth.

\subsection{Black (aswad,د_اســــ (l)}

a. Colour basic meaning = black (-)

The primary symbolism of this colour is the colour of (black hair and black eye).

b.Extended meaning = dark (-)

From the anthropological extension of black in the Arabic culture, this colour refers to the negative or to unfavourable meanings or things which people do not like in the world, possibly because of the lack of light and the transparency of darkness such as the 'dark night' (Houghton, 2007 \& Salah,2006).

c.Additional meaning (+ -)

The additional semantic function of black in the Arabic culture is associated with the negative meanings, as given in the following examples:

i.Death $=$ In the Arabic culture, black is related to funeral. In addition, women wear black dress to show her sadness for the dead person. (-)

ii.Black hell = In Al-Quran, hell is usually associated as 'black and dark, punishment and suffering (-).

iii.Past decades $=$ Black in the Arabic flag refers to the past decades experience of war which means 'death for our country and people (-).

iv.Black crowd $=$ This usually associated with bad omen, sign or warning of danger (-).

v.Black heart $=$ This phrase is referred to as mean, cruel, or unkind (-).

vi.Bad luck $=$ This is a negative meaning which is used to refer to a black chance or fortune (-).

vii.Black cat $=$ This is a common meaning in the Arabic superstitions, which is thought to cause bad luck (-).

It is also important to highlight that the colour black in the Arabic culture is sometimes used with positive connotations, such as:

viii.Black petrol $=$ This is usually implied to rich, powerful, wealthy $(+)$.

ix.Black eyes $=$ This is a symbolism of the beautiful black big eyes of the Arab women (+).

x.Black dress $=$ This implies elegance, stylish, and smart. Some Arabs wear black abiah, men and women which signifies elegance and respect for their culture $(+)$.

\subsection{Green (akhthar, خصـا)}

a. Colour basic meaning $=$ green $(+)$

The third colour developed in the Arabic culture is green. Green is considered as a traditional colour of Islam, and this is likewise due to its association with nature. First, Muhammad is reliably quoted in Hadith, whereby "water, greenery, and a beautiful face" are the three universally good things. In the Qur'an, sura Al-Insan, believers in Allah in Jannah wore fine green silk.[31][32]

b. Extended meaning (goodness) $(+)$

It is clear from the anthropological extensions of green, this colour refers to the positive and favourable meanings which people like in the Arabic culture. In addition, green colour refers to the meaning of truthfulness and goodness. 
Traditionally, the additional semantic function of green, in the Arabic culture, is associated with the positive meanings as in the examples below:

i.Green hand = generous, kind, money.

ii.Green land $=$ growth, nature, grass, Palm tree.

iii.Green flag = the flag of Arab, indicating green colour, symbolizing their Islamist ideology.

iv.Green age = young, youthful, vigorous, maturity.

$\mathrm{v}$.Green light $=$ good sign .

2.4 Red (ahmar, حــــ)

a. Colour basic meaning $=$ red $(+)$

The primary symbolisms of red are blood and red rose (Houghton, 2007).

b. Extended meaning = love, passion $(+)$

In the Arabic culture, it is clear from the extended meaning of this colour that the colour red implies positive meanings, as explained earlier.

c. Abstract meaning (+ -)

i.Arab flag $\operatorname{logo}=$ as revolutionary army, brave army.

ii. Red cheeks $=$ shy.

iii. Red eye $=$ anger.

2.5 Blue (azraq, زرق/ )

a Colour basic meaning $=$ blue $(+)$

The basic or primary symbolism of this particular colour is the colour of nature (James, 2004). Just like green, blue plays a symbolic role in a number of world religions, and this is because it is the colour of the sky and sea, which is also related to the meaning of divinity.

b. Extended Meaning (-)

Although this colour is a symbolism for the colour of the nature, it holds the most extended and abstract negative meanings.

i.Blue eyes $=$ envy, jealousy.

ii.Blue body = death, Illness.

j.Abstract meaning (-)

i.Gloomy = cloudy, dark

ii.Depression $=$ sadness, misery

2.6 Yellow (asfar, صــن

a. Colour basic meaning = Yellow $(+)$

As with all other basic colours, the primary term of this colour is the colour of nature, as in the sun, autumn and the colour of the Arab land (desert) (Ibrahim, 2008).

b.Extended meaning $(+)$

The first abstracted meaning indicates only positive association, such as with 'gold'.

c.Abstract meaning (-)

The second abstracted additional meaning indicates negative functions such as:

i. Yellow face $=$ Envious, be jealous of.

ii. Yellow eye $=$ Sick, disease.

iii.Yellow smile $=$ Mean, cruel.

iv.Yellow journals $=$ dishonesty, untruthfulness.

v.Yellow snack $=$ sink your teeth into; bite off (a woman who hurts others).

In the present study, the semantic meanings of the six colour terms in the Arabic language were discussed and they 
were then compared to their English equivalents to find whether these (Arabic) colour terms portray any differences in their semantic meanings or whether they possess similar ways in extending their meanings, as in the universal order of their extension.

\section{The characteristics of the semantic extension of the colour terms}

Table 1 lists all the semantic functions of the six colour terms discussed in this study, and the representative semantic extensions of their equivalent English terms.

The comparisons presented in Table 1 below were not meant to be completed, particularly the ones in the English language. A number of efforts have been carried out to include all the representative examples of the Arabic words and their English correspondents, following which, the representative colour terms (which only exist in English) would then be identified. This was done in the attempt to achieve the following aims:

i) To find the similarities between the Arabic and English colour terms selected in this study;

ii) To find the semantic extensions of the colour terms related to either Arabic or English.

Thus, the comparison was carried out to identify and distinguish the semantic extension of the Arabic and English colour terms and these yielded results which are discussed in the subsequent section.

White: As discussed in the earlier section, white has developed extended abstract meanings from its etymological meaning of this particular colour in the Arabic culture. Moreover, it is not difficult to see the connection between the English and Arabic extended meanings as both Arabic and English use white to imply or refer to positive meanings (pure) and (clean). However, white in Arabic also has abstracted its extended meaning to refer to one kind of additional negative meaning such as coffin, whereas the same colour has extended its meaning to symbolize innocence and purity in English. Based on these findings, the extended meanings of white in English (innocent and pure) are fundamentally different from its additional meanings in Arabic, i.e. of coffin. Thus, it is crucial to highlight here that the same term, i.e. white has the same extended meaning of clean, purity and innocence in the two languages, but abstract its additional meanings in Arabic in two different directions, i.e. negative (coffin). Hence, it can be stated that this is not a case where people of different cultures recognize or understand a given colour term differently, the so-called language-anthropological differences, as some studies (e.g. Brown, 2005 \& Anna, 1990) suggest, that is, other than associated with the position of a certain semantic function in a language. That indicates that whichever semantic function developed earlier can determine the direction and scope of the semantic function to be developed later. In other words, the Arabic language does not use white to imply the meaning of clean, innocence or purity; not because they do not distinguish the colour in such a way that the English people do, but this is rather due to the fact that the same colour has already developed an additional meaning (e.g. associated with negative - funeral). Based on this analysis, white could be used to convey the meaning, which to a certain degree, contradicts possible positive meanings such wedding, peace, virginity, etc. Once an established meaning such as 'coffin' has been fully inherent in the people's minds and culture, these meanings are nearly impossible to change.

Black: In Arabic and English, this particular colour conveys the same semantic negative and positive functions at all levels, namely the original meanings, extended meanings and additional meanings.

Green: The etymological meaning of green in the Arabic culture has a similar semantic function of the same colour in English. Both use the same semantic extension to refer to the positive natural, as in the colours of heaven and plants. Islam, for example, idolizes this colour, as it expects paradise to be full of green. Culturally, it is also associated with growth, regeneration, fertility and rebirth for its connections to nature (Carruthers \& Sarah, 1996).

Red: Both Arabic and English use 'red' to refer to blood, love, passion, anger, revolution, etc. Nevertheless, they differ in the context that the Arabic culture associates it with a negative meaning, i.e. 'death'. In the Arabic culture, the person who is going to be executed wears red colour to refer to his punishment or the end of life. Whereas in English language, red has extended its meaning to a positive direction, such as with Santa Claus, who has a red costume, to mark the beginning of New Year or new life (Thomas,2005). In addition to this, red also symbolizes Valentine's Day of love. It is also evident that both cultures also relate the meaning of red to the negativity such as anger or red eyes from blood/fire. These two positive and negative meanings were developed through people's anthropology or perception of red throughout their culture or behaviour. Thus, it would be contradictory or confusing for red to develop the type of negative meanings which have evolved for red in Arabic and English. In other words, it is unlikely for the same colour term to develop contradictory meanings within a language.

Blue: Though this colour is natural as in the colour of the sea and sky, its semantic extension in the Arabic culture refer to the same semantic extension or meaning of black. Due to the fact that this colour has the most negative meanings (such as death, sadness, depression, sickness, etc.), blue also implies the negative colour of sadness and depression in English (Oslie, 2000). Thus, what was estimated from this colour was the extended abstract meanings 
of blue, which do not contradict with the existing meanings. Based on these facts, it was therefore suggested in this study that the negative meaning of blue was derived from the colour of skin after death in both cultures.

Yellow: The use of yellow in Arabic and English has a number of common negative functions; among other, they both express the meanings of sickness, weakness, envious, lies, etc.) (Kalat, 2005). Interestingly, it conveys the positive meaning of the natural yellow to gold and autumn in both Arabic and English. For instance, the colour of plants becomes yellow in autumn and this consider as a sign for the beginning of new life (Abdul Aziz, 2008 \& Ibrahim, 2008). The current study suggested that these positive and negative meanings had been developed based on the people's understanding of 'yellow' throughout their cultures. In other words, it is a result of the etymological effects or influence of the human's behavior on their language and culture.

In a nutshell, this study compared the semantic functions of the six Arabic colour terms to their English counterparts and found that they share more similarities than differences in their extensions. The findings of the current study are summarized as follows:

i. Negative and positive extended and additional abstract meanings of the colour terms were found to be developed through the people's experiences with these terms.

ii. The common extended and additional meanings of the six colour terms, in both languages, were extended from their original or natural meanings. This could be due to the people's understanding of the colour terms and their experiences, which are generally similar, regardless of their cultural language and background.

iii. Most extensions of the six colour terms in Arabic were found to be the same or similar to those of their English counterparts.

iv. Etymology and anthropology are two primary methods involved in the semantic extension of the colour terms.

\section{Conclusion}

In the present study, the semantic extensions of the selected Arabic colour terms were examined, and for this purpose, the focus was given to the similarities and differences involved in the development of their various semantic extensions. Based on the analysis and the results gathered, it was found that the Arabic and English colour terms possess more common functions than differences. Results also provided evidences which supported that the language etymology of the colour terms in both cultures were not accidental, as they were found to be systematically developed based on the already existing semantic extensions of these colour terms and the fact that whether there is a potential contradiction between the existing meaning and the prospective new meaning. Hence, it can be concluded that the present study has shown that the semantic extension of the original meaning of the colour terms can simultaneously be extended into several meanings and these extended meanings can be further expanded into several abstract additional meanings.

The classification of the six colour terms in both languages was further categorized into two types - positive and negative meanings, and this was done based on the researchers' understanding of the cognition between language and experience. Evidently, it is human's nature which relates a descriptive linguistic symbol (green) to something which is in the physical world (e.g. grass), and then express an opinion about the described object in the world (the colour of land and heaven). Due to the fact that they are universally green or green land and that heaven is universally believed to be good, it is natural for green to extend its meaning to positive connotations, which could predictably mean either a positive or a negative meaning. This also explains why the six colour terms in Arabic, discussed in this study, have a number of similar semantic functions as their English counterparts.

In the current study, the comparison led the researchers to conclude that the extension of colours is purely cognitive and has been stimulated by the people's own understanding of their real experiences. This supports Brown's (2005) view which suggests that "the language the people use has a strong influence on the perception of the world, in addition to the concepts of colours which are anchored in certain universal of human experiences."

\section{References}

Abdul Aziz, A. (2008). Derasah Mauthuiaa Faneiah, Al-Jazerah Journal, Al-Riyadh. No. 5534.

Anna, W. (1990). The Meaning of the Colour Terms: Semantic, Culture and Cognation. Cognitive Linguistics, 1:99-150. doi:10.1515/cogl.1990.1.1.99, http://dx.doi.org/10.1515/cogl.1990.1.1.99

Barno, J. \& Svoronos, P.D.N (2005). Handbook of Fundamental Spectroscopic Correlation Charts. CRC Press. doi:10.1201/9781420037685, http://dx.doi.org/10.1201/9781420037685

Baxter, W. (1983). A Look at the History of Chinese Colour Terminology. Journal of Chinese Language Teachers 
Association, 18(2):1-25.

Brown, K. (2005). Encyclopaedia of Language and Linguistics (2nd ed.). Oxford: Elsevier.

Carruthers, G. \& Sarah B. (1996). The Colour of Money and Nature of Value: Greenbacks and Gold in Postbellum America. The American Journal of Sociology, 101: 6. doi:10.1086/230867, http://dx.doi.org/10.1086/230867

Hay, D., Margolis, E., Naroll, R. and Perkins, D.R. (1972). Colour Term Salience. American Anthropologist, 74:1107-1121. doi:10.1525/aa.1972.74.5.02a00050, http://dx.doi.org/10.1525/aa.1972.74.5.02a00050

Houghton, M. (2007). The American Heritage Dictionary of the English Language (4th Edition, 2000, 2007). Houghton Mifflin Company.

Ibrahim, M. (2008). Adab Abdul Aziz A. Derasah Mauthuiaa Faneiah, Al-Refaee press. Al-Riyadh.p.p 223.

James, M. (2004). Celtic Mythology. A Dictionary of Celtic Mythology. In James M. (ed.) 1998, 2004.

Kalat, J.W. (2005) Introduction to Psychology. Thomson Wadsworth, 105.ISBN 053462460X.

Oslie, P. (2000). Life Colours: What the Colours in Your Aura Reveal. Novato, California: New World Library Blue Auras.

Salah, S.A. (2006). Connotation and Cross Cultural Semantics. Translation Journal, Vol.10, No.4.

Skeat, W. (2000). The Concise Dictionary of English Etymology, repr ed., Diane. (ISBN 0-7881-9161-6).

Sura 76, The Human (Al-Insaan) Quran the Final Testament, Translated by Rashad Khalifa. PhD.

Tao, W. (1994). Colour Terms in Shang Oracle Bone Inscriptions. Bulletin of the School of Oriental and African Languages, 59(1): 63-101. doi:10.1017/S0041977X00028561, http://dx.doi.org/10.1017/S0041977X00028561

Wilson, R \& Keil F. (1999). MIT Encyclopedia of the Cognitive Sciences. Cambridge, Mass: MIT Press.

Xing, J.Z. (2008). Semantics and Pragmatics of Colour Terms in Chinese. Washington: Western Washington University.

\section{Notes}

Note 1. Etymology is the branch of linguistics which studies the origin and development of words and other linguistic forms. The examples of the areas covered include the earliest origins of a word, how their meanings and connotations have changed, the meanings and origins of the component parts, whether or how they have spread to other languages, and how the meaning or use have been influenced by other words. The history of a word is also known as 'etymology' (Skeat, 2000).

Note 2. Anthropological linguistics deals with describing many languages and issues such as the influence of language on the behavior of the community that uses it. The well-known Sapir-Whorf hypothesis is a result of such investigations. This theory suggests that the language that people use has strong influence on the perception of the world. Therefore, anthropolinguists deal with problems such as how people who share the same culture might speak different languages, and the people who have different cultures sometimes share a language (Brown, 2005). 
Table 1. Arabic and English colour terms

\begin{tabular}{|c|c|c|}
\hline Colour & Arabic & English \\
\hline $\begin{array}{c}\text { White } \\
\text { (abiath, ابيض) }\end{array}$ & $\begin{array}{c}\text { clean }(+) \\
\text { pure }(+) \\
\text { clear }(+) \\
\text { peace }(+) \\
\text { wedding, virginity }(+) \\
\text { white lies }(+) \\
\text { prayers }(+) \\
\text { future }(+) \\
\text { dove }(+) \\
\text { coffin }(-) \\
\text { white hand }(+) \\
\text { white heart }(+) \\
\text { white face }(+) \\
\text { white hair }(+) \\
\text { white day }(+) \\
\text { white days }(+)\end{array}$ & $\begin{array}{c}\text { clean }(+) \\
\text { pure, innocent }(+) \\
\text { clear } \\
\text { white flag of truce, White Revolution }(+) \\
\text { wedding }(+) \\
\text { white lie }(+) \\
\text { White House }(+) \\
\text { as white as snow }(+)\end{array}$ \\
\hline Black (aswad,اسود) & $\begin{array}{c}\text { dark }(-) \\
\text { death }(-) \\
\text { black hell }(-) \\
\text { black heart (-) } \\
\text { past decades }(-) \\
\text { black crowd (-) } \\
\text { bad luck (-) } \\
\text { black cat (-) } \\
\text { black petrol }(+) \\
\text { black eyes }(+) \\
\text { black dress }(+)\end{array}$ & $\begin{array}{c}\text { as dark as night }(-) \\
\text { death }(-) \\
\text { black hell (-) } \\
\text { black heart (-) } \\
\text { black list (-) } \\
\text { black market (-) } \\
\text { gloomy (-) } \\
\text { evil (-) } \\
\text { fear (-) } \\
\text { black magic (-) } \\
\text { black dress }(+)\end{array}$ \\
\hline $\begin{array}{c}\text { Green } \\
\text { (akhthar, اخضر ) }\end{array}$ & $\begin{array}{c}\text { green land }(+) \\
\text { green light }(+) \\
\text { energy }(+) \\
\text { green age }(+) \\
\text { green hand, goodness }(+) \\
\text { green flag }(+) \\
\end{array}$ & $\begin{array}{c}\text { green grass }(+) \\
\text { green light }(+) \\
\text { energy, vigorous }(+) \\
\text { youthful }(+) \\
\text { money }(+)\end{array}$ \\
\hline $\begin{array}{c}\text { Red } \\
(\text { (ahmar, احمر) }\end{array}$ & $\begin{array}{c}\text { love }(+) \\
\text { passion }(+) \\
\text { red face, shy }(-) \\
\text { Arab flag logo }(+) \\
\text { blood }(+) \\
\text { brave army }(+) \\
\text { death }(-) \\
\text { red eye, anger }(-) \\
\text { red crescent }(+) \\
\text { red rose }(+) \\
\text { red stone }(+)\end{array}$ & $\begin{array}{c}\text { love }(+) \\
\text { passion }(+) \\
\text { red face, shy }(-) \\
\text { red flag }(+) \\
\text { blood }(+) \\
\text { red race }(+) \\
\text { Santa Claus }(+) \\
\text { anger }(-) \\
\text { red cross }(+) \\
\text { red rose }(+)\end{array}$ \\
\hline $\begin{array}{c}\text { Blue } \\
\text { (ازرق,azraqu) }\end{array}$ & $\begin{array}{c}\text { depression (-) } \\
\text { blue body, death (-) } \\
\text { gloomy (-) } \\
\text { blue eye, envy (-) }\end{array}$ & $\begin{array}{c}\text { feel blue, depressed (-) } \\
\text { blue blood, death (-) } \\
\text { blue sky, gloomy/ winter (-) }\end{array}$ \\
\hline $\begin{array}{c}\text { Yellow } \\
\text { (asfar, اصفر ) }\end{array}$ & $\begin{array}{c}\text { gold(+) } \\
\text { autumn(+) } \\
\text { yellow face, sick (-) } \\
\text { yellow journals(lies) } \\
\text { yellow eye, sick(-) } \\
\text { yellow smile(envy) } \\
\text { yellow snack(envy, jealousy) }\end{array}$ & $\begin{array}{c}\text { yellow gold }(+) \\
\text { autumn }(+) \\
\text { cowardice, weakness (-) } \\
\text { yellow journalism (-) } \\
\text { Juandese, sick (-) }\end{array}$ \\
\hline
\end{tabular}

